\title{
STRATEGIES TO IMPROVE QUALITY OF DATA DISSEMINATION WEBSITE: A CASE STUDY OF THE CENTRAL BUREAU OF STATISTICS
}

\author{
Betty Purwandari, Infaz Rizki Adawati, Puspa Indahati Sandhyaduhita and Iis Solichah \\ Faculty of Computer Science, Universitas Indonesia \\ Depok 16424, Indonesia
}

\begin{abstract}
E-government facilitates the use of Information Technology to establish government public services. A common feature of e-government is a Website as public portal. One of prominent institutions in Indonesia, which is obliged to provide the Website is the Central Bureau of Statistics. However, a data requirement survey by the Central Bureau of Statistics in 2017 indicated a gap between user expectation and user satisfaction of the Website. Besides, an assessment by the Open Data Inventory (ODIN) indicated that the Website has not met the international Website quality criteria, especially data completeness and data openness measures. To address this problem, a research was conducted to investigate its shortcomings and propose strategies for improvement. The data were collected using questionnaires, which were grouped into the Importance Performance Analysis (IPA) matric quadrants. It was followed by literature studies and interviews with experts in statistical Website to propose improvement strategies. The priority of strategies was compiled using the Quality Functional Deployment (QFD). The results show that the Central Bureau of Statistics are required to optimize the Website code, redesign the Website layout, create statistical data forum, conduct statistical capacity building, and improve the data interoperability. Lesson learned from this research and its findings are potential to be adopted in other emerging economies, which strive to provide qualified data on e-government Websites to their citizens.
\end{abstract}

\section{KEYWORDS}

Website Quality, Importance Performance Analysis, Quality Functional Deployment

\section{INTRODUCTION}

E-government requires efforts to establish the government services by leveraging the Information Technology and the Internet (Parent, 2005). The use of Information Technology in e-government would ease both the service manager and the service user (Panagiotopoulos, 2012). Through e-government, the government could deliver better, efficient, transparent, and responsible services. Consequently, it will increase citizen participation and trust to the government (Panagiotopoulos, 2012; Parent, 2005).

The Indonesia government has the concern about the e-government, as stated in the President Instruction Number 3, 2003, in the e-government implementation policy and national strategy, that the government should improve the efficiency, effectivity, transparency, and accountability of the public services through e-government (Presiden RI, 2003). It is also stated in the Administrative and Bureaucratic Reform Ministry Regulations, Number 19, 2016, that the ministry supports the use of the Information Technology to improve the public services (Menpan RI, 2016). And it is also stated in the President Regulations, Number 95, 2018, about the electronic based government, that one of the strategy to improve the e-government, the electronic based and public oriented services, is by building a public service portal (Presiden RI, 2018).

In the international, the Open Data Watch (ODW) establishes some assessments to the National Statistics Office (NSO) in various countries (180 countries in 2017), to score the official national statistics as one of the e-government services, based on ten elements of coverage and openness. The resulted score for each country assessed are put in the ODIN (Open Data Inventory). For a country to get the higher score of coverage and openness, should pay attention to the ten elements assessed by the ODW. For Indonesia, the most important layer who is responsible about this score is the Central Bureau of Statistics. Therefore, Indonesia needs to put some efforts to enhance the e-government services of the Central Bureau of Statistics. 
The Central Bureau of Statistics is a non-ministry agency whose responsible to establish the governmental works related to statistical data. the Central Bureau of Statistics provides some services to disseminate the statistical data to the data users in two ways: offline and online. The offline service enables users to drop in the Central Bureau of Statistics office to request the needed data offline. However, the online service is very important to support the e-government program. It enables non-staff users to access the statistical data via the Central Bureau of Statistics data dissemination Website and submit a data request via the online forum, while the Central Bureau of Statistics staff users could access the data via the Publication Information System, which is integrated with the Central Bureau of Statistics data dissemination Website. This study takes this Website as a case study to investigate strategies for required improvement to enhance data coverage and openness.

The Central Bureau of Statistics Strategic Plan 2015-2019 states that one of the Central Bureau of Statistics vision is "Improving the prime services to provide the statistical activity results" and that one of the strategic targets is "Improving the quality of user engagement" (Badan Pusat Statistik, 2015). One of the realizations is to disseminate the statistical data via the Central Bureau of Statistics Website. To support its vision, the Central Bureau of Statistics conducted the annual data requirement survey since 2005 to identify the needs and level of satisfaction of the data users, and finally to improve the data dissemination service. The user satisfaction level could be investigated by comparing the service quality to fulfill the user needs and the user expectations (Al-Hawary, S. I. S., 2016).

The data requirement survey measures the level of service importance and the level of user satisfaction using the $1-4$ Likert scale. The survey results in 2017 (Table 1) shows a gap between the user expectations and the level of user satisfaction in the following aspects: easiness to find data, data completeness, communication between the user and the Central Bureau of Statistics staffs, easiness of Website access, and the tidiness of the Website layouts. It indicates that the Central Bureau of Statistics data dissemination Website still need some improvements to achieve the user expectations.

The ODW assessment also indicated that the Central Bureau of Statistics requires improvement as shown in Figure 1. The Indonesia's Central Bureau of Statistics Website was in the 27th rank of the 180 NSO Websites and in the 2nd rank in the Southeast Asia, after the NSO Singapore Website. Specifically, the Central Bureau of Statistics Website is in the 3rd rank after Singapore and Philippine in the data openness assessment category, in the Southeast Asia (Open Data Watch, 2017). We could conclude that the Central Bureau of Statistics Website has not yet fulfilled the assessment criteria of the ODW.

Similar problems were faced by public sectors in different countries (Hasan L., 2011). Therefore, this investigation was conducted to design strategies to improve quality of the Central Bureau of Statistics data dissemination Website. The processes and findings can be adopted in other countries with similar background to Indonesia. The assessment of a Website's quality is often challenging, as well as important to better meet citizen needs and satisfaction. The research question is then formulated as "How is the Central Bureau of Statistics data dissemination Website improvement strategy design to fulfill the user expectations and the international assessment criteria?"

Table 1. The data requirement survey in 2017 (Badan Pusat Statistik, 2017)

\begin{tabular}{lll}
\hline Assessment Aspects & User Expectation & User Satisfaction \\
\hline Easiness to find the data & 3.71 & 3.01 \\
Public collections completeness & 3.64 & 2.98 \\
Easiness to communicate via email & 3.60 & 3.02 \\
Easiness to obtain the Central Bureau of Statistics & 3.66 & 3.08 \\
products & & \\
Easiness to access the Central Bureau of Statistics & 3.74 & 3.23 \\
Website & & \\
the Central Bureau of Statistics data is free from other & 3.64 & 3.19 \\
parties' intervention & & \\
Easiness to search the publication collections & 3.59 & 3.16 \\
Easiness to communicate via telephone/faximile & 3.59 & 2.99 \\
The availability of complaints procedures & 3.54 & 3.15 \\
The products are tidy and formal & 3.30 & 3.13 \\
\hline
\end{tabular}




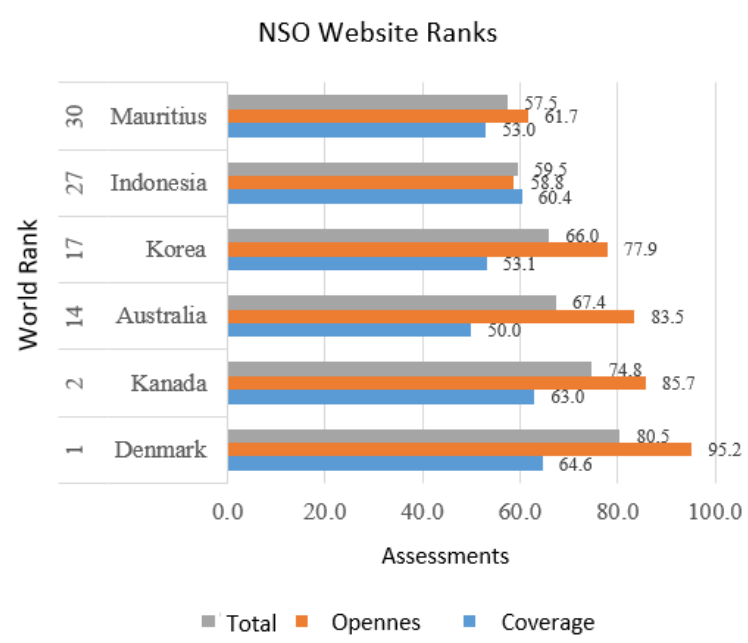

Figure 1. National Statistic Office Website Ranks, Open Data Watch 2017 (Open Data Watch, 2017)

The introduction to this investigation is discussed in section 1. It is followed by theoretical study in section 2 and research methods in section 3. The results are discussed in section 4 and concluded in section 5.

\section{THEORETICAL STUDY}

\subsection{Importance Performance Analysis (IPA)}

The Importance Performance Analysis (IPA) is a method of decision making by prioritizing the improvement strategies, determining which organization resources is the most needed by the users. This method is also used to enhance the competitiveness of the organization (Martilla, J.A., 1977; Azzopardi, E., 2013).

The IPA Matric classifies the research attributes into four quadrants:

1. Keep up the good work: The service attributes which lied in this quadrant are the main power of the organization and should be maintained. In this quadrant, the organization has put some amount of resources effectively to fulfill the users' needs.

2. Possible overkill: The service attributes which lied in this quadrant are considered less important by the users, but need some high efforts by the organization. This quadrant shows that the amount of resources in the service could be moved to the other more important services.

3. Low priority: The service attributes which lied in this quadrant are considered less important by the users, while the service quality is also not satisfactory. The organization could ignore these attributes.

4. Concentrate here: This quadrant contains the attributes with the highest priority and the most critical to the organization infestations, while the service quality is still not satisfactory. These attributes could be a threat to the organization if they are not improved. The organization should focus its improvement strategies on these attributes.

\subsection{Quality Function Deployment (QFD)}

The Quality Function Deployment (QFD) is a systematic design method to improve products, and to help the business to fulfill the users' needs (Chen, Y. T., 2011). It could transform the users' needs into a product or service characteristics specification. The QFD involves four matric in the house of quality which covers six types of needs as follows:

1. The user needs (The what).

2. The evaluation of needs (The why). 
3. The technical needs (The how).

4. The relationship matric between the user needs and the technical needs (The what vs the how).

5. The correlation matric, i.e. the relationship matric among the technical needs (The how vs the how)

6. Technical achievements (The how much).

The formulated relationships are then ranked to obtain the highest priority user needs. The QFD could be combined with the other methods to get the better results (Khorshidi, H. A., 2016). The steps to compose the house of quality are as follows (Murali, S., 2016):

1. Identify the user needs (the whats). Obtained from the "concentrate here" and the "keep up the good work" quadrants of the IPA matric.

2. Form the prioritization based on the sum of the importance level values. The QFD scale value is obtained by calculating the average of the importance level values.

3. Identify the improvement strategies to fulfill the users' needs. This could be conducted by some brainstorming and interviews with the organization executives and the other parties involved in providing the services.

4. Develop the relational matric between the what and the how. The relationships between the what and the how are then assessed to identify the relationships between the user needs and the recommended improvement strategies. The strength of the relationship is shown in the value of 0-1-3-9 (from the weakest to the strongest relationship) (Fabiś-domagała, J., 2017).

5. Prioritize the strategies. The value of each of the strategy item is obtained by summing the relational matric result value with the relative weight of the user needs. The highest value is the most important strategy.

\subsection{Theoretical Framework}

The authors formulate a theoretical framework of this research as shown in Figure 2, containing the following items:

1. Comparing the existing Website quality measurement models

This step is conducted to identify the research dimensions and attributes. The models involved are: the ODIN (Open Data Watch, 2017), the webQual 4.0 (Barnes, S. J., 2005) and the e-GovQual (Papadomichelaki, $X ., 2012)$. The identified dimensions and attributes are then used to develop the research questionnaires. The used dimensions are: information quality (Napitupulu, D., 2017), reliability (Papadomichelaki, X., 2012), usability and service interaction (Barnes, S. J., 2005).

2. Regulations

The used dimensions and attributes are the one that is in line with the Central Bureau of Statistics dissemination regulations. Those regulations are:

a. The Law Number 16, 1997 about the statistics.

b. The Law Number 14, 2008 about the public information openness.

3. Data Processing using the IPA Matric.

4. Data Processing using the QFD method.

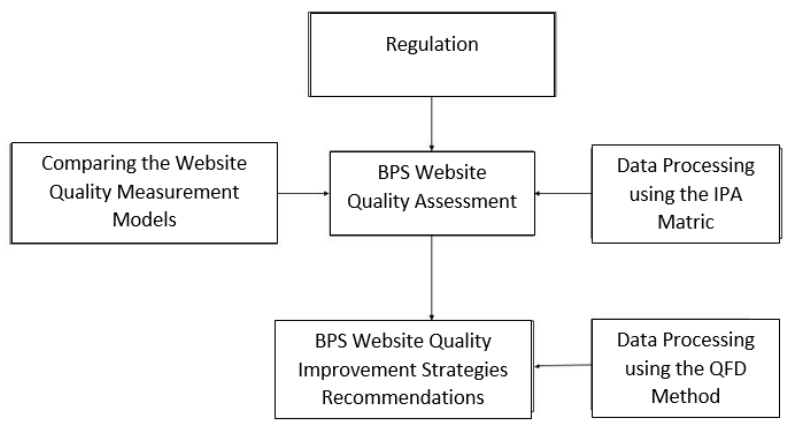

Figure 2. Research Theoretical Framework 


\section{RESEARCH METHODS}

The research methodology in this study is depicted in Figure 3. This research was established by a continuous communication with the Statistics Dissemination Directorate, the Central Bureau of Statistics. The object of research is the Central Bureau of Statistics data dissemination Website. The respondents of this research are selected from the Website user community using the purposive sampling method. The data was collected online from November $23^{\text {rd }}$ to $30^{\text {th }}, 2018$, using the online Google Forms features. The online questionnaires are distributed via the Email and WhatsApp groups. Several 2.350 user emails are contacted, which are obtained from the Central Bureau of Statistics Website admin.

The questionnaire consists of two main parts: respondent demography and Website quality measurement. The first part contains some questions about the respondent's profile, including some specific questions about their experience in accessing the Central Bureau of Statistics Website, to ensure that the respondents are really the Website users. The second part contains some questions about the following Website quality dimensions: information quality, reliability, usability, and service interaction. There are thirty $1-5$ Likert scale questions in total. A reliability and validity test were conducted to make sure that all question items are valid.

The IPA Matric is used to create a prioritization of the Website attributes which lied in the "concentrate here" and "keep up the good work" quadrants, as the "what" of the IPA Matric. To produce the "how" of the IPA Matric, i.e. the improvement strategies recommendations, the authors conduct some document studies, literature studies (Kesuma, D. P., 2014), and study the discussions delivered by Head of the Central Bureau of Statistics (Suhariyanto, 2018) and Deputy of Statistics Information Methodology, the Central Bureau of Statistics (Nugraha, M. A., 2018) in the yearly coordination meeting.

The formulated solutions (the improvement strategies recommendations), i.e. "the how" of the QFD Matric are then validated by conducted some interviews with the executives, who are responsible in the Central Bureau of Statistics data dissemination Website management. The improvement strategies recommendations are then processed using the Quality Function Deployment (QFD) method to determine the prioritizations of the strategies. The Relationship and Correlation Matrices are composed by some brainstorming activities involving the authors and the Central Bureau of Statistics Website team.

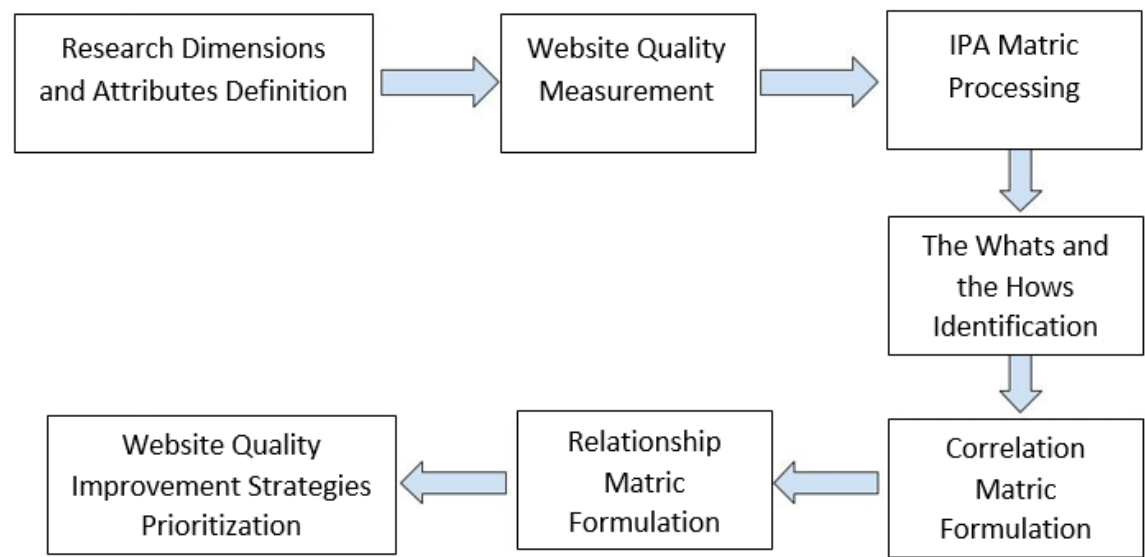

Figure 3. Research Methodology

\section{RESULTS}

The completeness and consistency of the collected answers from the respondents are investigated to filter which data to be included in the data processing step. Any incomplete, duplicated, or inconsistent data are excluded from the research. All valid answers about the service quality and the level of importance attributes are mapped into the IPA matric quadrants. The average value of each attributes is also calculated, to measure the quality of the Central Bureau of Statistics Website. 
The next stage is to design the improvement strategy. The "what" of the IPA Matric as listed in Table 2 shows the Website attributes which need special attention from the Central Bureau of Statistics because those attributes lied in the "concentrate here" and the "keep up the good work" quadrants in the IPA matric. The "hows" of the IPA Matric as listed in Table 3 shows the strategies needed by the Central Bureau of Statistics to improve the quality of the attributes in the "what" part. The "what" and the "how" are treated as the input for composing the Relationship and Correlation Matrices to prioritize the strategies.

The produced Correlation Matric shows that there are some positive relations among the solutions, as follows:

1. "Introduce some statistical data forums" and "Improve the data interoperability"

2. "Introduce some statistical data forums" and "Establish some capacity building activities bringing the statistics topics"

3. "Improve the data interoperability" and "Establish some capacity building activities bringing the statistics topics"

4. "Improve the infrastructure supports" and "Integrate the system databases"

5. "Improve the infrastructure supports" and "Optimize the Website code"

6. "Integrate the system databases" and "Optimize the Website code"

7. "Redesign the Website user interface layout" and "Optimize the Website code"

The produced Relationship Matric as given in Table 4, gives the priorities among the strategies. The higher the value, the higher the priority of the strategy, and vice versa.

Table 2. The What of the IPA Matric Attributes

\begin{tabular}{ll}
\hline Dimension & The What Attributes \\
\hline Information & The format of the provided data is easy to be processed by the computer \\
Quality & The provided data is complete to the user needs \\
& The provided data is accurate \\
The provided data is easy to be understood & The provided data is neutral \\
& The provided data is trusted \\
& The provided data is up to date \\
\hline Reliability & The Website could be accessed well using the desktop browser \\
& The Website could be accessed well using the laptop browser \\
& The Website could be accessed well using the tablet browser \\
& The Website could be accessed well smartphone browser \\
& The Website always successfully appears in the browser in the first access to the www.bps.go.id \\
& The Website is available and could be accessed anytime it is needed \\
\hline Usability & The Website is easy to use \\
The Website has clear menus and easy to use \\
The Website has an effective search feature to help searching certain data \\
\hline Service & The user believes that his/her username and password is secure to download the statistics data \\
Tnteraction & The user believes that his/her private data entried to the Website is saved securely
\end{tabular}

Table 3. The Hows of the IPA Matric Attributes

\begin{tabular}{ll}
\hline Code & Improvement Strategies \\
\hline TR1 & Introduce some statistical data forums \\
TR2 & Improve the data interoperability \\
TR3 & Establish some capacity building activities bringing the statistics topics \\
TR4 & Improve the infrastructure supports \\
TR5 & Elaborate the possibility of using the open data portal in Indonesia \\
TR6 & Establish some surveys on the users' data needs \\
TR7 & Integrate the system databases \\
TR8 & Put the user guideline in the Website \\
TR9 & Optimize the Website code \\
TR10 & Put a data security guarantee statement in the Website \\
TR11 & Redesign the Website User Interface layout \\
\hline
\end{tabular}


Table 4. The Website Improvement Strategies Prioritization

\begin{tabular}{llll}
\hline Priority & Code & Value & Improvement Strategies \\
\hline 1 & TR9 & 27.39 & Optimize the Website code \\
2 & TR11 & 26.28 & Redesign the Website User Interface layout \\
3 & TR1 & 11.44 & Introduce some statistical data forums \\
4 & TR3 & 9.84 & Establish some capacity building activities bringing the statistics topics \\
5 & TR2 & 5.43 & Improve the data interoperability \\
6 & TR5 & 4.93 & Elaborate the possibility of using the open data portal in Indonesia \\
7 & TR8 & 4.88 & Put the user guideline in the Website \\
8 & TR10 & 3.29 & Put a data security guarantee statement in the Website \\
9 & TR4 & 3.27 & Improve the infrastructure supports \\
10 & TR6 & 2.16 & Establish some surveys on the users' data needs \\
11 & TR7 & 1.09 & Integrate the system databases \\
\hline
\end{tabular}

\section{CONCLUSIONS}

This research integrates the IPA and QFD methods to investigate the prioritization of the Website improvement strategies, by adopting the steps of research conducted by the (Murali, S., 2016) and adding the following improvements:

1. The Murali's research uses the value of 5-3.1-0 to determine the relationship between the problem (the what) and the solution (the how). While the authors use the value of 9-3-1-0, adopted them from the research of (Fabiś-domagala, J., 2017) to show the difference significance among the strategies.

2. The Murali's uses the brainstorming method to collect the how as the organization's technical solution. The brainstorming is conducted between the executive board and the service unit. While in this research, the authors conduct some literature and document studies and then validate the information by some interviews with the organization's experts: the executives, who are responsible in managing the Website.

Based on this research, some improvement strategies are suggested for the Central Bureau of Statistics data dissemination Website. Some suggestions (from the highest to the lowest priority) in the information quality dimension are as follow:

1. Introduce some statistical data forums to accommodate some discussions between the data provider and data users.

2. Establish some capacity building activities bringing the statistics topics.

3. Elaborate the possibility of using the open data portal.

4. Establish some surveys on the users' data needs.

5. Integrate the system databases.

Some suggestions (from the highest to the lowest priority) in the reliability dimension are as follow:

1. Optimize the Website code.

2. Redesign the Website User Interface layout.

3. Improve the supporting infrastructures.

Some suggestions (from the highest to the lowest priority) in the usability dimension are as follow:

1. Put the user guideline in the website.

2. Optimize the Website code.

3. Redesign the Website User Interface layout.

The first suggestion in the service interaction dimension is to show a formal statement from the Central Bureau of Statistics, which guarantees the security of the users' privacy data. The second one is to review and analyze the Website code to improve the Website security.

This study also suggests some recommendations for further related research:

1. Conduct a depth analysis to overcome the IPA quadrant's border determination problem. So far, the attributes which are lied on the border of two quadrants in the IPA matric are difficult to interpret (Azzopardi, E., 2013).

2. Include not only the government regulations which are related to data view, but also the one related to the government Website management.

3. Conduct some data triangulation to verify the validity of the experts' explanations in the interviews, and to enrich the research discussions. 
This research is limited to the data dissemination Website of the Central Bureau of Statistics in Indonesia. However, the processes and findings have potential contribution to meet the gap of references on e-government Website quality advancement, especially in the developing world.

\section{ACKNOWLEDGMENT}

This publication is supported by the PIT 9 grant, Universitas Indonesia (NKB-0006/UN2.R3.1/HKP.05.00/2019).

\section{REFERENCES}

Al-Hawary, S. I. S., \& Al-menhaly, S. M, 2016. The Quality of E-Government Services and its Role on Achieving Beneficiaries Satisfaction. Global Journal of Management and Business Research: A Administration and Management, 16(11).

Azzopardi, E., \& Nash, R., 2013. A critical evaluation of importance-performance analysis. Tourism Management, 35, 222-233. https://doi.org/10.1016/j.tourman.2012.07.007

Badan Pusat Statistik, 2015. Rencana Strategis (Renstra) Badan Pusat Statistik (BPS) 2015-2019.

Badan Pusat Statistik, 2017. Analisis Hasil Survei Kebutuhan Data, XXXIII(2), 81-87.

Barnes, S. J., \& Vidgen, R. T., 2005. Data triangulation in action: using comment analysis to refine web quality metrics. Ecis, (2005), 24.

Chen, Y. T., \& Chou, T. Y. (2011). Applying GRA and QFD to Improve Library Service Quality. Journal of Academic Librarianship, 37(3), 237-245. https://doi.org/10.1016/j.acalib.2011.02.016

Fabiś-domagała, J., 2017. Quality function deployment method for selected Website usability analysis. Czasopismo Techniczne, 9, 165-171. https://doi.org/10.4467/2353737XCT.17.157.7169

Hasan, L., \& Abuelrub, E., 2011. Assessing the quality of web sites. Applied Computing and Informatics, 9(1), 11-29. https://doi.org/10.1016/j.aci.2009.03.001

Kesuma, D. P., 2014. Integrating E-SERVQUAL and Kano Model into Quality Function Deployment to Improve Website Service Quality: An Application to University's Website, 35. https://doi.org/10.4018/978-1-4666-97645.ch003

Khorshidi, H. A., et al, 2016. Statistical process control application on service quality using SERVQUAL and QFD with a case study in trains' services. TQM Journal, 28(2), 195-215. https://doi.org/10.1108/TQM-02-2014-0026

Martilla, J. A., \& James, J. C., 1977. Importance-Performance Analysis. Journal of Marketing, 41(1), 77. https://doi.org/10.2307/1250495

Menpan RI, 2016. Peraturan Menteri Pendayagunaan Aparatur Negara dan Reformasi Birokrasi Republik Indonesia Nomor 19 Tahun 2016, 1-20.

Murali, S., et al, 2016. Integration of IPA and QFD to assess the service quality and to identify after sales service strategies to improve customer satisfaction - A case study. Production Planning and Control, 27(5), $394-407$. https://doi.org/10.1080/09537287.2015.1129463

Napitupulu, D., 2017. Analysis of Factors Affecting The Website Quality (Study Case: XYZ University). International Journal on Advanced Science, Engineering and Information Technology, 7(3), 792. https://doi.org/10.18517/ijaseit.7.3.1748

Nugraha, M. A., 2018. Upaya Sinkronisasi Data Statistik Sektoral melalui Penerapan Prinsip-Prinsip Satu Data. Jakarta: Badan Pusat Statistik

Open Data Watch, 2017. 2017 Methodology Report of Open Data Inventory. Akron, Inc.

Panagiotopoulos, P., et al, 2012. A business model perspective for ICTs in public engagement. Government Information Quarterly, 29(2), 192-202. https://doi.org/10.1016/j.giq.2011.09.011

Papadomichelaki, X., \& Mentzas, G., 2012. E-GovQual: A multiple-item scale for assessing e-government service quality. Government Information Quarterly, 29(1), 98-109. https://doi.org/10.1016/j.giq.2011.08.011

Parent, M., et al, 2005. Building citizen trust through e-government. Government Information Quarterly, 22(4), $720-736$. https://doi.org/10.1016/j.giq.2005.10.001

Presiden RI, 2003. Instruksi Presiden Republik Indonesia Nomor 3 tahun 2003. Istr, (Undang-Undang Informasi dan Transaksi Elektronik), 1-25.

Presiden RI, 2018. Peraturan Presiden Republik Indonesia Nomor 95 Tahun 2018 tentang Sistem Pemerintahan Berbasis Elektronik.

Suhariyanto, Kecuk., 2018. Sambutan Kepala BPS dalam Rakor Pusdatin dan Diskominfotik. Jakarta: Badan Pusat Statistik 